FITRAH Jurnal Kajian Ilmu-ilmu Keislaman

Vol. 05 No. 1 Juni 2019

e-ISSN : 2460-2345, p-ISSN: 2442-6997

Web: jurnal.iain-padangsidimpuan.ac.id/index.php/F

\title{
FUNDRAISING BAGI PEMBERDAYAAN PENDIDIKAN PADA PANTI ASUHAN HAFIZHIL YATAMU KOTA PADANGSIDIMPUAN
}

\section{Darliana Sormin dan Samsidar}

Universitas Muhammadiyah Tapanuli Selatan, Padangsidimpuan

Email: darliana.sormin@um-tapsel.ac.id

\begin{abstract}
Fundraising is one of the main forms of funding sources for education expenses. Through fundraising, these educational institutions and community organizations will be helped in implementing the organization's vision and mission. Fundraising activity is to raise funds from the private sector and the community, especially for educational purposes. Fundraising is carried out because of the desire to meet the needs of institutions or organizations, funds that are desired by institutions and organizations can be obtained in many ways, as bazar, the students' handicraft expo, service, micro business, social institution (as orphanage, nursing home, LSM), and Zakat Institution (as BAZNAS, LAZISMuh, Dompet Dhu'afa, Baitul Maal Mualamat).
\end{abstract}

Key Words: fundrising, education, Hafizil Yatamu Orphanage

\section{Abstrak}

Fundraising merupakan salahsatu bentuk sumber dana untuk biaya pendidikan, melalui fundraising ini lembaga pendidikan maupun lembaga kemasyarakatan akan terbantu dalam melaksanakan visi misi dari organisasi. Kegiatan fundraising adalah menghimpun dana dari pihak swasta dan masyarakat terutama untuk kepentingan pendidikan. Fundraising (penggalangan dana) dilaksanakan karena adanya keinginan untuk memenuhi kebutuhan lembaga atau organisasi, dana yang yang diinginkan lembaga dan organisasi tersebut dapat diperoleh melalui banyak cara, seperti: bazar, expo hasil karya siswa, jasa, usaha mikro, lembaga sosial seperti panti asuhan, panti jompo, LSM, lembaga Amil Zakat seperti BAZNAS, BASDA, LAZISMuh, Dompet Dhu'afa, Baitul Maal Muamalat.

Kata Kunci: Fundraising, pendidikan, Panti Asuhan Hafizhil Yatamu 
FITRAH Jurnal Kajian Ilmu-ilmu Keislaman

Vol. 05 No. 1 Juni 2019

\section{PENDAHULUAN}

Sumber dana pendidikan adalah semua pihak-pihak yang memberikan bantuan subsidi dan sumbangan yang diterima oleh lembaga sekolah, baik dari lembaga sumber resmi ataupun dari masyarakat sendiri secara teratur. Contoh dari sumber dana atau biaya yang berasal dari lembaga resmi adalah sumbangan dari pemerintah pusat Anggaran (APBN), pemerintah daerah (APBD), sselanjutnya ada dari wali murid berupa Sumbangan Pembinaan Pendidikan (SPP), dan dari masyarakat (Jariyah). ${ }^{1}$ Sumber lain mengatakan bahwa sumber dana atau biaya pendidikan adalah keseluruhan biaya yang berasal dari masyarakat, orang tua, dan pemerintah. ${ }^{2}$

Fundraising merupakan kegiatan menghimpun, baik dana maupun bentuk lainnya, dari individu atau lembaga, dengan beragam cara, untuk kemudian disalurkan kembali kepada yang berhak menerimanya. Untuk melaksanakan kegiatan penghimpunan secara maksimal, sebuah lembaga perlu membangun kepercayaan (trust) yang kuat, pengelolaan dana yang profesional dan juga program pendayagunaan yang unggul, yang dampaknya terasa signifikan oleh masyarakat.

Fundraising (penggalangan dana) dilaksanakan karena adanya keinginan untuk memenuhi kebutuhan lembaga atau organisasi, dana yang yang diinginkan lembaga dan organisasi tersebut dapat diperoleh melalui banyak cara, seperti: bazar, expo hasil karya siswa, jasa, usaha mikro, lembaga social seperti panti asuhan, panti jompo, LSM, lembaga Amil Zakat seperti BAZNAS, BASDA, LAZISMuh, Dompet Dhu'afa, Baitul Maal Muamalat.

Lembaga pendidikan dan organisasi kemasyarakatan melakukukan fundraising harus memahami strategi dan metode penggalangan dana agar dapat dilaksanakan dengan maksimal dan mengetahui dana yang diperoleh tersebut akan disalurkan untuk masyarakat membutuhkan, baik untuk pendidikan, UKM, maupun untuk kesejahteraan masyarakat pada umumnya.

Hampir semua lembaga sosial dan kemasyarakat menghimpun dana untuk kepentingan pendidikan, tetapi ada juga yang untuk usaha mikro dan bantuan bencana alam seperti ACT (Aksi Cepat Tanggap). Banyak juga kita jumpai di masyarakat lembaga yang melakukan penggalangan dana dengan cara

${ }^{1}$ Nanang fattah, Ekonomi dan Pembiayaan Pendidikan (Bandung: PT.Remaja Rosdakarya, 2006), hlm. 113

2Martin, Manajemen Pembiayaan Pendidikan : konsep dan aplikasinya (Jakarta:PT.Rajagrafindo Persada, 2014), hlm. 8. 
premitif (tradisional) misal dengan membawa map atau meminta-minta sehingga tidak bertahan lama, ini disebabkan karena tidak memiliki keahlian dalam fundraising.

Panti asuhan merupakan organisasi atau lembaga sosial kemasyarakatan yang bergerak di bidang pendidikan, sumber pendanaannya berasal dari bantuan masyarakat baik dari donator tetap maupun dari masyarakat yang datang langsung ke panti asuhan. Panti asuhan ini tidak menerima bantuan dari pemerintah semua murni dari masyarakat dan dana tersebut dikelola lembaga ini dalam bentuk unit usaha sehingga ke depannya lembaga ini bisa mandiri, dan pengelolaan dana yang masuk dan keluar setiap 2 kali dalam sebulan dilaporkan dalam bentuk tertulis dan disampaikan dalam rapat rutin.

Berdasarkan latarbelakang ini penulis tertarik membahas penggalangan dana di panti asuhan, yang sampai sekarang masih tetap amanah dalam menjalankan peran nya untuk membantu masyarakat kurang mampu agar dapat melanjutkan pendidikan. Adapun tujuan penelitian ini adalah untuk mengetahui dan mendeskripsikan bagaimana bentuk fundraising dan pengelolaan dana di Panti Asuhan Hafizhil Yatamu Kota Padangsidimpuan

\section{PEMBAHASAN}

\section{Penggalangan Dana dalam Praktek Islam}

Fundraising juga bisa di artikan sebagai kegiatan dalam rangka menghimpun dana dari masyarakat dan sumber daya lainnya dari masyarakat (baik individu, kelompok, organisasi, perusahaan ataupun pemerintah) yang akan digunakan untuk membiayai program dan kegiatan operasional organisasi sehingga mencapai tujuannya. Dari pengertian di atas dapat di simpulkan bahwa strategi fundraising adalah rencana sebuah proses mempengaruhi masyarakat agar mau melakukanamal kebajikan dalam bentuk penyerahan dana atau sumber daya lainnya yang bernilai, untuk disampaikan kepada masyarakat yang membutuhkan.

Penggalangan dana dalam pandangan Islam identik dengan penghimpun dana yang biasanya dilakukan oleh lembaga zakat, infak, sedekah dan Wakaf. Dalam Undang-undang penghimpunan zakat diatur bagaimana lembaga zakat menjalankan fundraising, salahsatunya undang-undang No. 38 tahun 1999 
FITRAH Jurnal Kajian Ilmu-ilmu Keislaman

Vol. 05 No. 1 Juni 2019

tentang pengelolaan zakat dan didalamnya banyak bab yang membahas tentang penggalangan dan penyaluran zakat. ${ }^{3}$

Lembaga Wakaf pada masa Bani Saljuk, Nizam Al-Mulk tahun $457 \mathrm{H}$ dimana kedudukan pendidikan menduduki posisi sangat penting sehingga pengelolaan dana wakaf sudah dialokasikan untuk biaya pendidikan dan untuk kesejahteraan rakyatnya. ${ }^{4}$ Nizam Al-Mulk tidak sungkan-sungkan mengeluarkan biaya besar dari anggaran tahunan kerajaan demi kepentingan dan kemajuan pendidikan. Nizam Al-Mulk pun menyediakan beasiswa untuk mahasiswa dan memberi mereka fasilitas asrama. Mereka yang tinggal di asrama diberi uang belanja secukupnya, Ia memberi bantuan untuk semua pelajar tanpa mengharap kembali dan seluruh biaya pendidikan di madrasah Nizamiyah itu gratis. Dalam pembangunan madrasah, Nizam Al-Mulk menyediakan dana wakaf untuk membiayai mudarris, imam, dan mahasiswa yang menerima beasiswa dan fasilitas asrama. Dengan dana tersebut, Ia mendirikan madrasah-madrasah Nizamiyah di hampir seluruh wilayah Dinasti Saljuk dan mendirikan perpustakaan lebih kurang 6.000 jilid buku lengkap dengan katalognya. ${ }^{5}$

\section{Metode dan Strategi Fundraising}

Dalam melaksanakan kegiatan fundraising, banyak metode dan teknik yang dapat dilakukan. Adapun yang dimaksud metode disini adalah suatu bentuk kegiatan yang khas yang dilakukan oleh sebuah organisasi dalam rangka menghimpun dana dari masyarakat. Metode ini pada dasarnya dapat dibagi kepada dua jenis, yaitu langsung (direct fundraising) dan tidak langsung (indirect).

a. Metode Fundraising Langsung ( Direct Fundraising ) ${ }^{6}$

Yang dimaksud dengan metode ini adalah metode yang menggunakan teknik-teknik atau cara-cara yang melibatkan partisipasi donator secara langsung. Yaitu bentuk-bentuk fundraising dimana proses interaksi dan daya akomodasi terhadap respon donatur bisa seketika (langsung) dilakukan.

\footnotetext{
${ }^{3}$ Undang-Undang No. 38 tahun 1999 tentang pengelolaan Zakat dan penyaluran zakat

${ }^{4}$ Dasim Budimansyah, Ilmu dan Aplikasi Pendidikan, Tim Pengembangan Ilmu Pendidikan (IMTIMA: Bandung, 2007), hlm. 315

${ }^{5}$ Dewan Redaksi Ensiklopedi Islam, Ensiklopedi Islam jilid 4, cetakan ke-10 (Jakarta : PT Ichtiar Baru Van Hoeve, 2002), hlm. 44-45.

${ }^{6}$ Hendra Sutisna, Fundraising Database (Depok: 2006) Cet 1, hlm. 11
} 
Dengan metode ini apabila dalam diri donator muncul keinginan untuk melakukan donasi setelah mendapatkan promosi dari fundraiser lembaga, maka segera dapat melakukan dengan mudah dan semua kelengkapan informasi yang diperlukan untuk melakukan donasi sudah tersedia. Sebagai contoh dari metode ini adalah: Direct Mail, Direct Advertising, Telefundraising dan presentasi langsung.

b. Metode Fundraising Tidak Langsung ( Indirect fundraising ) ${ }^{7}$

Metode ini adalah suatu metode yang menggunakan teknik-teknik atau cara-cara yang tidak melibatkan partisipasi donator secara langsung. Yaitu bentuk-bentuk fundraising dimana tidak dilakukan dengan memberikan daya akomodasi langsung terhadap respon donatur seketika. Metode ini misalnya dilakukan dengan metode promosi yang mengarah kepada pembentukan citra lembaga yang kuat, tanpa diarahkan untuk transaksi donasi pada saat itu. Sebagai contoh dari metode ini adalah: advertorial, image compaign dan penyelenggaraan Event, melalui perantara, menjalin relasi, melalui referensi, dan mediasi para tokoh.

Pada umumnya sebuah lembaga melakukan kedua metode fundraising ini (langsung atau tidak langsung). Karena keduanya memiliki kelebihan dan tujuannya sendiri-sendiri. Metode fundraising langsung diperlukan karena tanpa metode langsung, muzakki akan kesulitan untuk mendonasikan dananya. Sedangkan jika semua bentuk fundraising dilakukan secara langsung, maka tampak akan menjadi kaku, terbatas daya tembus lingkungan calon donator dan berpotensi menciptakan kejenuhan. Kedua metode tersebut dapat digunakan secara fleksibel dan semua lembaga harus pandai mengkombinasikan kedua metode tersebut.

Dari kedua metode tesebut yang paling sering digunakan yakni metode langsung. Karena dengan menggunakan metode langsung calon donator akan timbul rasa kepercayaan untuk menyumbangkan dana-dananya untuk dikelola dalam lembaga tersebut khususnya dalam lembaga Fundraising misal dana ZIS, karena dengan menggunakan metode langsung masyarakat atau calon donator akan lebih yakin dengan adanya suatu lembaga Fundraising tersebut.

${ }^{7}$ Hendra Sutisna, Fundraising Database, hlm. 11 
FITRAH Jurnal Kajian Ilmu-ilmu Keislaman

Vol. 05 No. 1 Juni 2019

Dalam menghimpun suatu dana pastinya membutuhkan strategi yang jitu. Tidak hanya dalam berbisnis, lembaga penghimpun dana juga memutuhkan strategi.

Strategi yang digunakan dalam mengumpulkan dana tersebut adalah:

1. Kampanye Media

Kampanye media adalah strategi yang dilakukan oleh suatu lembaga dalam rangka membangkitkan kepedulian masyarakat melalui berbagai bentuk publisitas pada media massa. Kampanye ini diarahkan kepada dua orientasi, yaitu yang pertama terbentuknya citra kondisi masyarakat yang kesulitan seperti contohnya penderitaan para korban bencana. Dan yang kedua adalah sosialisasi bahwa lembaga tersebut melakukan penghimpunan dana untuk membantu masyarakat yang kesulitan tersebut.

Beberapa tekhnik yang dilakukan antara lain :

a. Membuat Berita

Teknik ini dilakukan dengan cara membuat Press Release, undangan peliputan kegiatan, penyediaan kolom khusus informasi kegiatan, forum dialog atau diskusi dengan wartawan dan kunjungan kemedia massa.

b. Memasang Iklan

Teknik ini dilakukan dengan cara memasang berbagai iklan di media massa, baik iklan yang berisi gambaran tentang kondisi masyarakat yang kesulitan, untuk membangkitkan kesadaran publik maupun iklan yang berisi informasi bahwa lembaga tersebut melakukan penghimpunan dana dan membantu masyarakat yang sedang mengalami kesulitan. Iklan yang dipilih bisa berbentuk advertorial atau display.

\section{Direct Fundraising}

Direct fundraising adalah strategi yang dilakukan oleh lembaga dengan cara berinteraksi langsung dengan masyarakat, khususnya yang berpotensi menyumbangkan dananya. Strategi direct fundraising ini dilakukan dengan tujuan bisa mewujudkan donasi masyarakat atau langsung setelah terjadinya proses interaksi tersebut. Teknik yang dapat dilakukan antara lain: 

a. Direct Mail
b. Telefundraising
c. Pertemuan Langsung
d. Kerjasama Program
e. Fundraising Event.

\section{Fundraising bagi Pemberdayaan Pendidikan}

Terdapat dua masalah yang dihadapi pendidikan nasional, yaitu masalah pemerataan mutu dan pemerataan akses pendidikan. Merespon masalah tersebut, kemudian pemerintah mengeluarkan kebijakan-kebijakan, yang salah satu kebijakannya terkait dengan anggaran pendidikan, pemerintah menaikkan anggaran pendidikan menjadi $20 \%$ dari total anggaran nasional. Anggaran tersebut selain digunakan untuk meningkatkan mutu pendidikan nasional, juga untuk meningkatkan angka partisipasi sekolah masyarakat. Pemerintah untuk mensukseskan program pemerataan mutu dan pemerataan akses tersebut, memberikan bantuan operasional sekolah (BOS) kepada sekolah/madrasah.

Terbatasnya anggaran pendidikan nasional, meski telah dinaikkan menjadi $20 \%$ dari total anggaran nasional, dan besarnya jumlah sekolah/madrasah di tanah air sebagaimana disebut di atas, menunjukkan bahwa pemerintah sampai saat ini belum mampu sepenuhnya mengatasi problem pendidikan nasional, terutama terkait soal anggaran. Dalam konteks inilah, pemerintah berharap partisipasi masyarakat, terutama Sekolah/Madrasah Swasta untuk turut secara proaktif mencerdaskan bangsa. Hal ini juga termaktub dalam Permendikbud Nomor 75 Tahun 2016: Komite Sekolah Boleh Galang Dana, "Penggalangan dana dan sumber daya pendidikan lainnya berbentuk bantuan dan/atau sumbangan, bukan pungutan," bunyi Pasal 10 ayat (2). ${ }^{8}$ Hasil penggalangan dana tersebut dapat digunakan antara lain: (a). Menutupi kekurangan biaya satuan pendidikan; (b). Pembiayaan program/kegiatan terkait peningkatan mutu sekolah yang tidak dianggarkan; (c). Pengembangan sarana/prasarana; dan (d). Pembiayaan kegiatan operasional Komite Sekolah dilakukan secara wajar dan dapat dipertanggung jawabkan. Sementara penggunanaan hasil penggalangan dana oleh Sekolah harus:

a. Mendapat persetujuan dari Komite Sekolah.

b. Dipertanggungjawabkan secara transparan; dan

8 Permendikbud Nomor 75 Tahun 2016: Komite Sekolah Boleh Galang Dana 
FITRAH Jurnal Kajian Ilmu-ilmu Keislaman

Vol. 05 No. 1 Juni 2019

c. Dilaporkan kepada Komite Sekolah.

Pihak yang paling mendapatkan tantangan pendanaan adalah Sekolah/Madrasah Swasta. Dibanding Negeri, Sekolah/Madrasah Swasta dituntut lebih kreatif dan inovatif dalam menggalang dana untuk memenuhi kebutuhan pendidikan yang bermutu. Bagi sekolah/madrasah Negeri pembiayaan dan pendanaan pendidikan hampir tidak menjadi masalah, karena sebagian besar sumber dana pendidikan berasal dari pemerintah pusat dan daerah. Sementara sumber dana dari masyarakat hanya sebagian kecil saja. Namun bagi Sekolah/Madrasah Swasta ini tentu menjadi masalah tersendiri. Berbeda dari negeri, sumber sekolah/madrasah swasta justru sebagian besar berasal dari masyarakat. Mereka dituntut lebih kreatif dan inovatif dalam mengatasi persoalan biaya dan pendanaan pendidikannya. ${ }^{9}$

Mengatasi permasalahan pendanaan di sekolah, maka salahsatu upaya adalah dengan melakukan penggalangan dana. Penggalangan dana bisa dilaksanakan sekolah dalam bentuk bazar dan expo hasil kreatifitas sekolah, yangmana produk tersebut dipasarkan dalam acara atau event yang dilaksanakan pemerintah atau antar lembaga pendidikan, produk yang dihasilkan sekolah kemudian diajukan untuk di urus HaKI (Hak Kekayaan Intelektual) yang berguna untuk peningkatan mutu sekolah.

\section{Pentingnya Fundraising Bagi Masyarakat}

Sumbangan masyarakat yang di galang oleh lembaga kemasyarakatan dijelaskan dalam peraturan pemerintah Pasal 4 Peraturan Pemerintah Nomor 16 Tahun 2015 bahwa sumbangan masyarakat sebagaimana meliputi: a. Barang; b. Uang; dan/atau c. Surat berharga. ${ }^{10}$

Lembaga kemasyarakatan sebagian besar juga melakukan penggalangan dana untuk membantu biaya pendidikan dengan memberikan bantuan kepada lembaga pendidikan yang membutuhkan dana misalnya lembaga (CSR), dan Lembaga sosial seperti panti asuhan juga melakukan penggalangan dana ke donator-donatur atau kepada para dermawan untuk dikelola sebagai dana pendidikan anak asuh.

Badan Amil Zakat Nasional (BAZNAS) dan lembaga ZISWAF lainnya juga melakukan penggalangan dana, yangmana dana tersebut juga dialokasikan

\footnotetext{
${ }^{9}$ Fahrurrozi, Jurnal Adminisistrasi Pendidikan Vol.XIV No.1 April 2012, hlm. 137

10 Peraturan Pemerintah Nomor 16 Tahun 2015, tentang sumbangan masyarakat
} 
untuk biaya pendidikan yang disalurkan dalam bentuk beasiswa dan membantu para mustahik dengan memberikan modal usaha sehingga bisa mendanai kehidupan mereka.

\section{METODE PENELITIAN}

Penelitian ini dilaksanakan di Panti Asuhan Hafizhil Yatamu Kota Padangsidimpuan. Jenis penelitian ini merupakan penelitian kualitatif. Penelitian kualitatif menurut Bogdan dan Biklen yang dikutip oleh Syukur Kholil adalah sebagai prosedur penelitian yang menghasilkan data deskriptif berupa kata-kata tertulis atau lisan dari orang-orang dan perilaku yang dapat diamati. ${ }^{11}$ Tujuan dari penelitian ini yaitu penelitian yang mengungkapkan pelaksanaan penggalangan dana di Panti Asuhan Hafizhil Yatamu Padangsidimpuan dengan menggunakan data-data yang bersifat naratif dan mendeskripsikannya serta dianalisis dengan menggunakan logika berpikir ilmiah. Berdasarkan taraf kedalaman analisis data, penelitian ini disebut dengan penelitian deskriptif. Penelitian dimaksud untuk memperoleh gambaran empiris berupa data dan fakta tentang penggalangan dana yang dilaksanakan Panti Asuhan Hafizhil Yatamu Kota Padangsidimpuan yang menjadi fokus dalam penelitian ini.

Adapun informan yang digunakan dalam penelitian ini adalah sebagai berikut:

a. Sumber Data Primer, yaitu: Pimpinan Panti Asuhan sebagai penanggung jawab.

b. Sumber Data Sekunder, yaitu: Pengurus dan anak asuh serta dokumen pendukung.

Teknik pengumpulan data merupakan cara yang digunakan peneliti untuk mendapatkan data dalam suatu penelitian. Pada penelitian kualitatif maka data yang diperoleh di observasi, wawancara dan dokumentasi mendalam, jelas dan spesifik. Seperti yang dijelaskan oleh Sugiyono bahwa pengumpulan data dapat diperoleh dari hasil observasi, wawancara, dan dokumentasi. ${ }^{12}$ Instrumen pengumpulan data yang digunakan dalam penelitian ini adalah: observasi, wawancara, dan dokumentasi. Observasi dilaksanakan peneliti terhadap kondisi fisik dan lingkungan Panti Asuhan Hafizhil Yatamu Padangsidimpuan. Hal-hal

${ }^{11}$ Syukur Kholil, Metodologi Penelitian Komunikasi (Bandung: Citapustaka Media, 2006), hlm. 121

${ }^{12}$ Sugiyono, Metodologi Penelitian Pendidikan: Pendekatan Kualitatif, Kuantitatif dan RED, (Bandung: Alfabeta, 2011), hlm. 225 
FITRAH Jurnal Kajian Ilmu-ilmu Keislaman

Vol. 05 No. 1 Juni 2019

yang diobservasi dalam penelitian ini meliputi: waktu, tempat, dan kondisi lingkungan di Panti Asuhan. Wawancara adalah sejumlah pertanyaan yang diajukan peneliti kepada informan penelitian untuk mendapatkan data tentang pelaksanaan Panti Asuhan Hafizhil Yatamu Padangsidimpun. Dokumen yang digunakan peneliti adalah dokumen yang ada terkait dengan penggalangan dana di Panti Asuhan Hafizhil Yatamu, meliputi: Struktur organisasi panti asuhan dan Sarana prasarana.

Adapun teknik penjaminan keabsahan data yang digunakan dalam penelitian ini yaitu:

a. Perpanjangan Keikutsertaan

Keabsahan pada penelitian ini diperoleh melalui perpanjangan waktu keikutsertaan peneliti dalam pengumpulan data di lapangan sampai kejenuhan pengumpulan data tentang pelaksanaan penggalangan dana di panti asuhan hafizhil yatamu Padangsidimpuan.

b. Ketekunan Pengamatan

Validasi data juga ditentukan oleh ketekunan dalam mengadakan pengamatan di lapangan dengan mengandalkan penglihatan, pendengaran, perasaan, dan insting peneliti.

c. Triangulasi

Perolehan data yang valid dapat diperoleh melalui pengecekan terhadap kejujuran, subjektivitas, dan kemampuan merekam data oleh peneliti di lapangan melalui triangulasi sumber data dan instrumen pengumpulan data.

Analisis data kualitatif menurut Moleong adalah analisis data yang dimulai dengan menelaah data sejak pengumpulan data sampai seluruh data terkumpul. ${ }^{13}$ Adapun langkah analisis data yang digunakan dalam penelitian ini adalah sebagai berikut:

1. Verifikasi Data

Verifikasi data bertujuan untuk menyeleksi atau memilih data yang sesuai dan memadai untuk diolah. Proses seleksi ditempuh dengan cara memeriksa dan menyeleksi kelengkapan data baik identitas maupun

${ }^{13}$ Lexy, J. Moleong, Metodologi Penelitian Kualitatif, (Bandung: Remaja Rosdakarya, 2013), hlm. 78 
jawabannya. Hasil yang diperoleh menunjukkan bahwa data memenuhi persyaratan untuk dianalisis.

2. Pengelompokan Data

Setelah penyeleksian data selesai, maka data dikelompokkan sesuai dengan keperluan analisisnya. Pengelompokan data bertujuan untuk mengelompokkan data berdasarkan kebutuhan jenis data yang diinginkan agar lebih mudah menganalisisnya.

3. Penyusunan Data

Langkah selanjutnya yang dilakukan adalah penyusunan data. Penyusunan data adalah menyusun data-data hasil penelitian berdasarkan kategorisasi yang sesuai dengan masalah penelitian.

4. Penyajian Data

Langkah selanjutnya yang dilakukan adalah penyajian data. Penyajian data adalah menyajikan data yang telah diperoleh sekaligus dengan analisis terhadap hasil penelitian tersebut.

5. Penarikan Kesimpulan

Langkah terakhir yang dilakukan peneliti adalah penarikan kesimpulan. Penarikan kesimpulan adalah inerpretasi dengan membandingkan konsep-konsep yang ada dengan hasil tersebut sehingga dimungkinkan lahirnya teori dari sini.

\section{HASIL PENELITIAN DAN PEMBAHASAN}

\section{Sejarah Singkat Panti Asuhan Hafizhil Yatamu}

Panti asuhan Hafizil Yatamu padangsidimpuan merupakan salah satu lembaga sosial yang berdiri sejak tahun 1992 di desa Sabungan Jae Kecamatan Hutaimbaru kota Padangsidimpuan, pendiri panti asuhan ini bernama bapak M. Djamil Rasyid. Lembaga ini bergerak di bidang pedidikan, yangmana dana yang diperoleh berasal dari masyarakat melalui sarana donator tetap, celengan, dan langsung datang ke panti asuhan untuk menyerahkan bantuan atau sumbangannya. Panti asuhan ini berdiri atas pemahaman pendirinya terhadap surah Al-Maun, yang intinya janganlah menghardik anak yatim, maka pendiri panti asuhan ingin memelihara anak yatim dan fakir miskin dengan memberikan kesempatan menikmati pendidikan sama seperti anak-anak yang lain.

Panti asuhan ini tidak menerima bantuan dari pemerintah, dana yang mereka peroleh murni dari masyarakat. Yayasan ini di pimpin oleh bapak M. 
FITRAH Jurnal Kajian Ilmu-ilmu Keislaman

Vol. 05 No. 1 Juni 2019

Isran Jamil anak dari bapak M. Djamil Rasyid dan ketua panti asuhan adalah bapak Muhammad Azmi. Bidang-bidang yang ada terdiri dari bidang pendidikan, bidang pengelolaan usaha, humas dan sosialisasi, bidang tamu dan donator, bidang pembinaan dan kebersihan dan dapur.

\section{Sarana dan Prasarana}

Sarana dan prasaaarana yang dimiliki oleh Panti Asuhan ini adalah sebagai berikut:
a. Mesjid
b. Asrama anak asuh
c. Kantor tamu
d. Kantor pengurus
e. Saung serba guna
f. Dapur
g. Ruang pertemuan bersama para dermawan
h. Gudang keperluan anak asuh
i. Gedung Asrama Tahfiz (sedang proses pembangunan)
j. Unit usaha panti
k. Rumah makan panti asuhan

\section{Kegiatan anak asuh}

Kegiatan terhadap anak asuh Panti Asuhan ini dilakukan selama 24 Jam, namun untuk aktifitas yang diawasi secara menyeluruh adalah sebagaimana tergambar dalam table di bawah ini:

Tabel 1: Kegiatan Anak Asuh

\begin{tabular}{|l|l|l|}
\hline No & \multicolumn{1}{|c|}{ Jam } & \multicolumn{1}{c|}{ Kegiatan } \\
\hline 1 & $04: 00-04: 30$ & Bangun dan sholat tahajjut \\
\hline 2 & $04: 30-05: 00$ & Tilawah Al-Quran + Sholat Shubuh \\
\hline 3 & $05: 00-06: 00$ & Al-Matsurah + Tahfiz \\
\hline 4 & $06: 00-06: 30$ & Mandi+Makan+Berangkat Sekolah \\
\hline 5 & $06: 30-12: 30$ & Aktivitas Sekolah \\
\hline 6 & $12: 30-13: 00$ & Sholat Zuhur \\
\hline 7 & $13: 00-15: 00$ & Makan+Istirahat siang \\
\hline 8 & $15: 00-15: 30$ & Bangun + persiapan sholat \\
\hline 9 & $15: 30-16: 00$ & Sholat Ashar \\
\hline 10 & $16: 00-16: 30$ & Ta'lim \\
\hline 11 & $16: 30-17: 30$ & Tahfiz+tambahan hafalan \\
\hline
\end{tabular}




\begin{tabular}{|l|l|l|}
\hline No & \multicolumn{1}{|c|}{ Jam } & \multicolumn{1}{c|}{ Kegiatan } \\
\hline 12 & $17: 30-18: 00$ & Persiapan mandi \\
\hline 13 & $18: 00-18: 30$ & Makan+persiapan sholat magrib \\
\hline 14 & $18: 30-19: 00$ & Sholat magrib+Ta'lim+Al-Waqiah \\
\hline 15 & $19: 00-19: 30$ & Tilawah+Sholat Isya \\
\hline 16 & $19: 30-21: 00$ & Kegiatan Tahfiz \\
\hline 17 & $21: 00-04: 00$ & Istirahat Malam \\
\hline
\end{tabular}

Tabel di atas berisi kegiatan wajib anak asuh, sementara kegaitan ekstrakurikuler uang dimiliki oleh Panti Asuhan ini tergambar dalam table di bawah ini:

Tabel 2: Kegiatan ekstrakurikuler

\begin{tabular}{|l|l|l|l|}
\hline No & Hari & Jam & Kegiatan \\
\hline 1 & Senin & $20: 30-22: 30$ & Beladiri \\
\hline 2 & Selasa & $04: 30-07: 00$ & $\begin{array}{l}\text { Safari Shubuh, } \\
\text { Rihlah, kursus } \\
\text { menjahit, berkuda, } \\
\text { memanah, berenang, } \\
\text { kunjungan }\end{array}$ \\
\hline 3 & Selasa & $21: 00-22: 00$ & Pengajian SUA \\
\hline
\end{tabular}

Kegiatan di Panti Asuhan ini diikuti pula oleh kegiatan program terbuka paket satu hari, yakni berlangsung pada setiap hari Ahad, pukul 09.00 - 13.00 dengan kegiatan Tahfiz dan Tahsin.

Kegiatan anak asuh ini dilaksanakan secara rutin dan sudah ada penanggungjawabnya, untuk pembinanya juga diambil dari luar panti asuhan, papan kegiatan ini di letakkan di luar sehinnga para tamu dan masyarakat bisa melihat semua aktivitas anak asuh.

\section{Kegiatan Fundrising Panti Asuhan}

Dari wawancara dengan ketua yayasan yang menjadi subjek penelitian diperoleh informasi sebagai berikut: Pada hari senin tanggal 03 Desember 2018, jam: 16:00 bersama bapak Isran selaku ketua yayasan, beliau menyampaikan bahwa,

"Panti asuhan ini sudah lama berdiri dan awalnya di Ujung Gurap kemudian pindah ke Aek Horsik, kemudian ke Pudun dan terakhir di sabungan jae sampai saat sekarang ini, panti asuhan ini didirikan oleh bapak Muhammad Rasyid Djamil, dan saya adalah anak dari bapak 
FITRAH Jurnal Kajian Ilmu-ilmu Keislaman

Vol. 05 No. 1 Juni 2019

rasyid, panti asuhan ini adalah milik keluarga dan dikelola secara bersama-sama oleh keluarga, yangmana sekarang anak dari bapak rasyid djamil yang mengelolanya." ${ }^{14}$

Wawancara berikutnya masih bersama bapak Isran, pada hari senin tanggal 03 Desember 2018, jam 16: 23 di Panti Asuhan,

"beliau menyampaikan terkait dana yang dikelola oleh panti asuhan merupakan dana yang murni dari masyarakat baik dalam bentuk donator tetap maupun para tamu yang langsung datang ke panti asuhan, dana dari masyarakat di kelola panti asuhan untuk biaya pendidikan anak asuh dan kebutuhan mereka sehari-hari, kemudian dana tersebut juga dikelola dalam bentuk unit usaha panti asuhan. Sampai sekarang ini unit usaha panti asuhan berupa ruamah makan HAYAT, usaha nasi goreng dan mie goreng serta bermacam jus yang di jual pada malam hari. Unit usaha lain panti asuhan adalah dengan membeli kebun dan usaha menerima atau menyediaakan jasa Aqiqah untuk masyarakat yang ingin melakukan aqiqah dip anti asuhan. Ke depannya kita akan buka sekolah tahfiz yangmana proses ini sebetulnya sudah berjalan 2 tahun tetapi hanya di buka kelas pada saat bulan ramadhon saja, untuk kedepan nya kita akan buka asrama khusus untuk penghafal Alquran, yangmana gedungnya sedang dalam proses pembangunan. Semoga segera terwujud, beliau sambil tersenyum harap..."15

Wawancara berikutnya dengan bapak Muhammad Azmi, pada hari selasa tanggal 04 Desember 2018 jam, 16:00.

Wawancara terkait kepengurusan sekarang bahwa pengelola dari panti asuhan ada 10 orang yang memiliki tugas-tugas dan amanah masingmasing, mereka menanggungjawabi beberapa bidang, yang terdiri dari bidang pendidikan, pembinaan, humas, unit usaha dan lain-lain. Terkait pelaporan dari semua bidang biasanya disampaikan pada rapat sekali

${ }_{14}$ Wawancara dengan ketua yayasan Bapak Isran Jamil, Hari Senin, tanggal 03 Desember 2018 di Panti Asuhan, jam: 16:00

${ }^{15}$ Wawancara dengan ketua yayasan Bapak Isran Jamil, Hari Senin, tanggal 03 Desember 2018 di Panti Asuhan, jam: 16:23 
dalam sebulan, tetapi rapat rutin pengurus setiap minggu pada malam kamis. ${ }^{16}$

Wawancara berikutnya masih bersama bapak Muhammad Azmi, pada hari selasa tanggal 04 desember 2018, jam, 16:30.

Kegiatan anak asuh dip anti ini sangat banyak dan beragam, diantaranya tahfiz, tapak suci, karate, berenang, memanah, berkuda, dan menjahit. Kegiatan ini dilaksanakan pada sore, malam dan pada hari minggu, para pelatih kita ambil dari luar. Kemudian ada juga kegiatan pengajian setiap hari selasa malam yang dilaksanakan oleh SUA Group yang mengikutsertakan anak asuh untuk mengikuti pengajian tersebut. Terkait pendidikan anak asuh, mereka semua sekolah diluar panti asuhan, tingkat pendidikan mereka mulai dari PAUD sampai SMA. Bagi anak asuh yang sudah tamat SMA maka mereka diwajibkan untuk mengabdi selama 1 tahun di panti asuhan terkecuali bagi anak asuh yang lulus tes di perguruan tinggi, maka mereka tidak diwajibkan untuk mengabdi. ${ }^{17}$

Semua kegiatan yang ada di panti asuhan dana nya bersumber dari masyarakat, dan masyarakat sangat senang karena mereka merasa bahwa bantuan yang mereka salurkan baik berupa zakat, infak, dan shadaqoh dipergunakan pada hal-hal yang sangat bermanfaat untuk keperluan anak asuh. Masyarakat yang datang banyak yang mengetahui keberadaan panti asuhan ini dari media massa seperti facebook dan google, begitu juga dengan anak asuh yang berasal dari berbagai daerah juga dapat info dari media massa.

Bidang humas banyak melakukan promosi terkait kegiatan anak asuh dan semua aktivitas atau berkembangan panti asuhan sehingga masyarakat luas mengetahui kegiatan anak asuh, dan memancing para donator dan masyarakat untuk berantusias membagi rezeki mereka ke panti asuhan tersebut.

Hasil wawancara pada hari rabu tanggal 05 desember 2018, jam, 16:00 terkait promosi ini,

Ibu Yusra selaku pengurus menjelaskan bahwa promosi panti asuhan dilakukan dengan menggunakan media social melalui fb dan bisa juga di

16 Wawancara dengan ketua panti asuhan Bapak Mhd Azmi, Hari Selasa, tanggal 04 Desember 2018 di Panti Asuhan, jam: 16:00

${ }^{17}$ Wawancara dengan ketua panti asuhan Bapak Mhd Azmi, Hari Selasa, tanggal 04 Desember 2018 di Panti Asuhan, jam: 16:30 
FITRAH Jurnal Kajian Ilmu-ilmu Keislaman

Vol. 05 No. 1 Juni 2019

lihat di google, dengan cara ini sangat banyak mendatangkan manfaat karena terbukti dari bertambahnya masyarakat yang membagi rezekinya ke panti asuhan kita, ini salahsatu cara kami melakukan penggalangan dana. Hasil dari dana atau amanah masyarakat di sosialisasikan ke media massa agar para donator mengetahui perkembangan panti asuhan. ${ }^{18}$

Panti asuhan ini sudah melakukan penggalangan dana (fundraising) untuk pendidikan anak asuh dan sudah melakukan penggunaan dana tersebut dengan baik. Panti asuhan ini merupakan lembaga social yang tidak menerima bantuan dari pemerintah sebagaimana hasil wawancara dengan ketua yayasan. Jadi penggalangan dana yang mereka peroleh murni dari masyarakat dan pertanggungjawabannya juga jelas dengan laporan secara luas melalui media massa.

\section{Pembahasan}

Panti Asuhan melakukan penggalangan dana untuk pendidikan anak asuhnya melalui lembaga-lembaga sosial, masyarakat, dan lain sebagainya. Sampai saat ini Panti ini masih tegak berdiri melakukan segala aktifitas sosialnya dengan dana yang terhimpun tersebut. Selain donatur tetap ada juga donatur yang tidak tetap, artinya hanya memberikan infak dan sumbangannya pada saat sata tertentu saja. Dari keterangan di atas diketahui bahwa Panti ini ternyata memiliki kemandirian. Kemandirina ini penting adanya, karena apabila mengharapkan dana dari donatur saja, tentu Panti ini tidak akan bisa bertahan hidup dalam memelihara anak-anak asuhnya. Terdapat pengaruh yang cukup signifikan dukungan masyarakat dengan segala aktifitas kegiatan Panti, bukan hanya saja pada kegiatan, mental, maupun juga pendanaan. Seperti halnya disampaikan oleh Fani dan Latifah $^{19}$ bahwa dukungan sosial masyarakat sekitarnya sangat membantu penyesuaian diri para remaja yang ada di Panti tersebut. Pengelolaan dana juga penting, sebagai pertanggungjawaban atas dana

18 Wawancara dengan pengurus panti asuhan Ibu Yusra, Hari Rabu, tanggal 05 Desember 2018 di Panti Asuhan, jam: 16:00

${ }^{19}$ Fani Kumalasari and Latifah Nur Ahyani, "Hubungan Antara Dukungan Sosial Dengan Penyesuaian Diri Remaja Di Panti Asuhan Latifah Nur Ahyani," Jurnal Psikologi Pitutur 1, no. 1 (2012): 21-31, https://jurnal.umk.ac.id/index.php/PSI/article/viewFile/33/32. 
yang telah terkumpul. Hal ini juga diperkuat oleh hasil penelitian Ma'rufah ${ }^{20}$ yang menyatakan bahwa sumber dana itu penting, namun pengelolaan yang profesioanl juga penting.

Hal ini tentu saja mendukung hasil penelitian di atas, dimana Panti Asuhan selain membutuhkan dana bagi kelangsungan hidup Panti tersbeut, juga memerlukan pengelolaan yang maksimal untuk hasil yang lebih maksimal.

\section{SIMPULAN}

Penggalangan dana (fundraising) merupakan salahsatu bentuk sumber dana untuk biaya pendidikan, melalui fundraising ini lembaga pendidikan dan kemasyarakatan akan terbantu dalam melaksanakan visi misi dari organisasi tersebut. Banyak lembaga pendidikan dan kemasyarakatan melakukan fundraising ini dengan metode dan strategi yang berbeda-beda, diantaranya:

1. Panti asuhan hafizhil yatamu sabungan jae padangsidimpuan ini berdiri pada tahun 1992, oleh bapak M. Rasyid Djamil, atas pemahaman beliau tentang surah Al-Maun. Pemahaman terhadap surah ini membuat pendirinya semangat dalam mendirikan pamti asuhan yang bertujuan untuk memberikan kesetaraan dan kesejahteraan untuk anak yatim, fakir miskin dan bagi anak-anak yang ingin melanjutkan pendidikan.

2. Sumber dana panti asuhan murni berasal dari masyarakat dan donator, yangmana dana tersebut dipergunakan untuk pendidikan anak asuh, baik untuk pendidikan formal maupun informal seprti pelatihan tapak suci, tahfiz, berkuda, karate, menjahit dan lainnya.

3. Panti asuhan ini melakukan penggalangna dana melalui media massa, seperti facebook melalui facebook khusus panti asuhan dan bisa juga di lihat melalui google. Sehinnga masyarakat mengetahui perkembangan panti asuhan.

\footnotetext{
${ }^{20}$ Nur Ma'rufah, “Sistem Pengelolaan Dana Yayasan Panti Asuhan Taman Thoyyibah Sedati Gede Sidoarjo" (IAIN Sunan Ampel Surabaya, 2009), http://digilib.uinsby.ac.id/7767/28/Nur Ma\%27rufah_B04205027.pdf.
} 
FITRAH Jurnal Kajian Ilmu-ilmu Keislaman

Vol. 05 No. 1 Juni 2019

\section{DAFTAR PUSTAKA}

Dasim Budimansyah, Ilmu dan Aplikasi Pendidikan, Tim Pengembangan Ilmu Pendidikan IMTIMA: Bandung, 2007

Dewan Redaksi Ensiklopedi Islam, Ensiklopedi Islam jilid 4, cetakan ke-10, Jakarta : PT Ichtiar Baru Van Hoeve, 2002

Fahrurrozi, Jurnal Adminisistrasi Pendidikan Vol.XIV No.1 April 2012

Hendra Sutisna, Fundraising Database, Depok: 2006

Kumalasari, Fani, and Latifah Nur Ahyani. "Hubungan Antara Dukungan Sosial Dengan Penyesuaian Diri Remaja Di Panti Asuhan Latifah Nur Ahyani." Jurnal Psikologi Pitutur 1, no. 1 (2012): 21-31.

https://jurnal.umk.ac.id/index.php/PSI/article/viewFile/33/32.

Martin, Manajemen Pembiayaan Pendidikan : konsep dan aplikasinya Jakarta: PT.Rajagrafindo Persada, 2014

Michael Norton, The Worldwide Fundraiser's Handbook. A Guide to Fundraising forNGOs and Voluntary Organisations, Copyright @ International Fundraising Group dan Directory of Social Change 1996 p. 4, Aplikasi llmu-ilmu Agama, Vol. V, No. 2, Desember 2004

Nanang fattah, Ekonomi dan Pembiayaan Pendidikan, Bandung: PT.Remaja Rosdakarya, 2006

Nur Ma'rufah. “Sistem Pengelolaan Dana Yayasan Panti Asuhan Taman Thoyyibah Sedati Gede Sidoarjo." IAIN Sunan Ampel Surabaya, 2009. http://digilib.uinsby.ac.id/7767/28/Nur Ma\%27rufah_B04205027.pdf.

Permendikbud Nomor 75 Tahun 2016: Komite Sekolah Boleh Galang Dana

Peraturan Pemerintah Nomor 16 Tahun 2015, tentang sumbangan masyarakat

Undang-Undang No. 38 tahun 1999 tentang pengelolaan Zakat dan penyaluran zakat 